\title{
THE IMPACT OF COVID-19 PANDEMIC ON MARKETING PHILOSOPHY
}

Ahmed E. Kamel 1,*

1 Doctorate of Business Administrations, Ain Shams University Head of Marketing \& Research at Damietta Container \& Cargo Handling co. Damietta Port.

\begin{tabular}{l} 
Keywords: \\
\hline 1- COVID-19 \\
2- Marketing \\
philosophy \\
3- marketing \\
strategy \\
4- customer \\
behaviour
\end{tabular}

Keywords:

\begin{abstract}
The impacts of COVID 19 on marketing philosophy are nearly unknown. The main objective of this paper is to provide a prime investigation on how Covid-19 pandemic can affect the developments of marketing, it also aims to provide more knowledge on how marketing philosophy are changing due to the pandemic. By following a qualitative research method, this paper outline how marketing could be affected by this pandemic and how it will change, not only the context of marketing, but also how businesses manage their strategic marketing efforts. The conclusion of this paper includes theoretical implications, recommendations, and suggestions for future research.
\end{abstract}

\section{INTRODUCTION}

The Covid-19 pandemic represents one of the most important environmental challenges in the modern marketing history, which could potentially have a strong effect on basic marketing philosophy. The shortrun effect of Covid-19 was clear and immediately noticed, due to the widespread lockdown and the applied of social distancing regulations worldwide.

In this paper, the researcher discusses some preliminary ideas on how this pandemic influence the marketing philosophy, the core marketing concepts, the context of marketing, and marketing strategy. The researcher tries to answer these questions: How are marketing philosophy affected by the Covid-19 pandemic? ; And how organizations approach their strategic marketing efforts?

\section{Methodology}

The qualitative research method is more suitable for this paper since the purpose is to explore and define how Covid-19 can affect marketing philosophy. This method used to describe, explore or explain a social phenomenon. Qualitative research allows the understanding through deeper analysis and various perspectives (Leavy, 2014).

\section{Data collection}

Interviews using Zoom and telephone calls are the primary data collection, which helps the researcher to obtain a deeper understand of the subject. The researcher also gathers data from scientific articles and journals and online resources due to the lack of previous research within marketing and Covid-19 pandemics.

\section{Literature review}

The Covid-19 or "coronavirus disease of 2019", first appeared in Wuhan, China. The virus spreads incredibly fast between people worldwide and within few months, hundreds of millions of people worldwide The Covid-19 outbreak caused fear for the way it is affecting the worldwide economy and the way it affected markets round the world. 
Such situation made big banks and institutions to lower the forecasts for the worldwide economy and a brand-new report from OECD mention that the 2020 growth forecasts have downgraded within the economies of all countries. Within the early 2020, the share for the worldwide economic process was $2.9 \%$, today that number has lowered to $2.4 \%$ (Nee Lee, 2020). In line with a report by the United Nations Conference on Trade and Development (2020), China's situation has been crucial to the world economy. China does not only hold an important role within the global economy due to its manufacturing industry and exporter of consumer goods, but they are also the most supplier of intermediate goods (raw materials and semi-finished goods) for manufacturing companies worldwide. Today, within the global trade manufacturing, around $20 \%$ of intermediate products originates from China. Many companies at once are forced to respond to multiple fronts directly, both the protection of their workers safety, additionally as protecting their operational viability as many of them are experiencing difficulties with their supply chains (Alicke et. Alt, 2020). Companies have to take many of prompt actions in response to Covid-19; these actions include optimizing production and distribution capacity, and to re-assess realistic final-customer demand. Some companies may experience inventory shortages due to the travel restrictions and lockdowns and thus it is important to arrange for these possible implications (McKinsey, 2020).

\section{The impact on marketing}

The author tries to explore how the pandemic has changed the core marketing concepts, the context of marketing, and marketing strategies.

\subsection{Core marketing concepts}

Covid-19 changes our life, so will the philosophies, ideologies, and fundamental principles that shaped marketing field. While much of these changes are difficult to predict, probably, these events will have a major effect on core marketing philosophies, mindsets, and ideas.

Marketing is grounded within the philosophy and beliefs of the marketing concept in which marketers and decision makers try to identify and answer the requirements and desires of targets markets better than competitors (see for instance Kotler, Armstrong, Harris, \& He, 2019). More organizations have believe in diversity of the societal marketing concept; wherein organizations balance short-term consumer wants and desires with the longterm prosperity of society (see Kotler \& Zaltman, 1971; Kotler et al., 2019). After Covid-19, buyers, societies, and organizations have to critically re-evaluate and question such philosophies and priorities. Economists, philosophers, and marketers have basic support long-termism while realworld pressures have restricted many policymakers, companies, and executives to adopt immediate concerns. Operational and shortterm goals promoted above longer-term objectives (see Anwar and Bassiouuny, 2020). Will the pandemic constitute a strong shock to marketers to question their firms and their core goals and ideologies? Today, it is difficult to predict the reflect on the price of people's life and business orientations, and their importance. Marketers have also defended the benefits of acknowledging and driving meaningful customer evaluations, satisfaction, and loyalty. Mid - pandemic consumers did not consider evaluations of varying brands or by long-term value; they were constrained by limited choice, product 
accessibility, and immediate demand. In some regards, instead of marketing myopia (Levitt, 1960) where marketers over-focus on the physical characteristics of their products, they focus on customer-hidden needs. Postpandemic theorists and practitioners could face a radical different marketing landscape and far changed customers. Opinions, beliefs, values, habits, and behaviors evolve because of both good and bad experiences; the Covid19 outbreak will sadly, have a sound impact on all of those. Pre-Covid, marketers were focused on the efficient and effectiveness of their value capturing from customers within the form of customer loyalty. Previously standards are clear same as solid metrics like customer lifetime value, share of customer, and customer equity, whereas Post-pandemic standards are likely to be critically questioned. It seems that such metrics are entirely disregarded; it seems that marketers and customers will tailor such measures. Some scholars argued that the marketing landscape was sharply changed from evolution to revolution (see Potts, 2018), the Covid-19 pandemic accelerated the changing process and the post-pandemic marketing will not be back as before. The dominance of face-to-face interactions and exchange declined by online exchange. Politicians and social commentators moved their views regarding online ex-change (See e.g., Abbruzzese \& Ingram, 2020). Communication methods between buyers and suppliers immediately changed as governments-imposed lockdowns and put resections on travel. WhatsApp, Microsoft team and Zoom, etc. The digital era of online, mobile, and social media marketing used very fast within few weeks.

According to GlobalData, a number of the most recent trends emerging following the Covid-19 pandemic include a dramatic shift toward e-commerce, increased shopping at one-stop-shop retailers. Covid -19 has accelerated the employment of technology in all aspects of consumers' lives. Thus, businesses have to increase their online presence to attach and interact with their clients. As brand loyalty are an occasional priority, consumers also are more likely to get from a less familiar brand that gives value-for-money. Consumers also are placing a high importance on self-care, mental state and physical wellness.

\subsection{The context of marketing}

While changes to core marketing concepts occurred and still happen, such changes will reflect the disturbance that Covid-19 caused within the marketing environment. Recessions, downturns, wars, revolutions, floods and earthquakes seem small things compared with global lockdowns that did not happen in the recent history. The marketing microenvironments of organizations hited by an enormous change that exceeds any previous fluctuations. The ways within which firms operate altered by social distancing and lockdowns that required major changes in operations and set-ups. The availability chain globally largely damaged during lockdown and national supply-chains stretched to breaking point across most industries and sectors. During the crises, customers see the distribution companies as national savers instead of merely companies hited by derived damned fluctuation. Across the world, restaurants switched from fine dining to takeout makers; fast-food deliverers expanded their role to become supermarket shoppers and deliverers (see Whitbread, 2020). Advertising and media companies have needed to develop campaigns and responses in days when earlier efforts took months and years. The context of competition has also 
changed. During the pandemic customers, publics, and governments required and, in some cases, forced, collaboration for the benefit of all. during this regard, past competitors became collaborators (see de Menzies, 2020).

In the marketing macro environment, fundamental changes happened; the consequences would stay for many years. Economically, the worldwide economy has been severely affected. Covid-19 measures closed entire sectors, forced industries to maneuver, and radically changed the character of consumer spending. Before lockdowns grocery, retailers specifically had unprecedented sales while online entertainment and connectivity organizations witnessed a massive increase in demand. Other sectors i.e. housing and automotive industries hard hited and the waves of fluctuating demand will likely continue for several years. Politically, most countries saw sweeping changes to ideologies that severely imposed on previously preferred systems of freedom of movement and market-economics amongst many others. The state took over many industries in many countries and therefore the long-run implications of this may resound within countries, regions, and global economies.

Technologically, politicians welcomed the net as a lifesaving medium, and the adoption of technology to switch face-to-face interaction was widespread. As such, media commentators have suggested that the pandemic forced twenty years of technology adoption in few days. Socially Covid-19 has changed and can change individuals', groups', managements', and governments' mindsets and philosophies. Culturally, people's views of themselves, of others, of organizations, of nature and of the universe have shifted. The precise nature of such shifts in our society and our culture is unclear but marketers should be at the forefront in exploring, explaining, and responding to such changes.

\subsection{Marketing strategy}

Changes to the marketing environment and landscape forced organizations to develop a strategic agility pre-, during-, and postpandemic. While strategists have long recommended agility in strategy making, the terrible speed of the spread of Covid-19 required organizations to develop such entrepreneurial agility on constitute flexibility to the purpose of responsiveness. While innovative researchers called for the necessity for strategic agility to form new markets that reach new customers, pandemic inspired and forced managers to develop systems, operations, and tactics to reach customers . Marketing strategy scholars will desire to explore such new agility and consider such flexibility in their strategic processes. Exploring, describing, and promoting such approaches should prove blooming and instructive.

What will the post-Covid-19 marketing strategy would involve? First, it seems probable that adopted organizational goals will change. Organizations reflecting on the post-pandemic world will have to re-evaluate their visions, missions, and their objectives to cope with the changes of their customers and competitors. Goals and objectives that incorporate long-term survival, strategic agility, and meaningful social responsibility, possibly centered on a societal marketing orientation are very possible.

The market oriented organizations reacted more effectively and efficiently than production oriented firms will prove interesting. Mid-pandemic governments and agencies rapidly adopted market-driving 
strategies to teach, control, and manage essential services, demand-supply, and public behavior. Post-pandemic research will specialize in how differing strategic orientations benefited or constrained organizational responses (especially in terms of responsive timeliness).

Post-pandemic competitor advantage will go to organizations that able to achieve first mover advantage. The post-Covid-19 marketplace is different. A key element is the increased move to online communications. Industries that previously relay on face-toface interaction have to find ways and means to interact (and survive) via online.

Another wonder element is the semi-collapse, partial failure and, at least, pausing of globalization.

\section{Analysis and discussions Impact of Covid-19 on Consumer Long- term behavior}

Covid-19 is changing consumers' attitudes, behaviors, and buying habits, and many of those changes are likely to stay postpandemic. As these changing consumer needs and behaviors will transform industries' future, they will pose both new challenges and opportunities for businesses. Thus, understanding these changing consumer behaviors is crucial for businesses when developing their business strategies to cope with the new and emerging consumer trends. Businesses must understand how their customers are reacting to the pandemic, and develop tailored marketing strategies to fulfill the wants of every customer group. According to GlobalData, a number of the most new trends emerging following the Covid-19 pandemic include a dramatic shift toward e-commerce, increased shopping at one-stop-shop retailers, and acceleration in buy local and personal label offerings. Covid19 has accelerated the employment of technology all told aspects of consumers' lives. Thus, businesses have to increase their online presence to attach and interact with their clients. As brand loyalty are an occasional priority, consumers also are more likely to buy from a less familiar brand that gives value-for-money. Consumers also are placing a high importance on self-care, mental state and physical wellness.

While most businesses face challenges associated with logistics and supply chain disruptions within the short term, businesses that rapidly adapt their business strategies to the newly emerging consumer needs and trends will differentiate themselves as longterm winners.

\section{Impacts of Covid-19 on Consumer's Shopping Behavior}

GlobalData's market intelligence reveals that consumers are increasingly placing vital importance on value-for-money. To mitigate the social and economic impacts of Covid-19, governments around the world have provided economic stimulus to households and businesses. While these economic stimuli have helped households and businesses to overcome financial hardships due to Covid19 , most of these supports are expiring in a matter of weeks or months. Thus, like the other sectors of the economy, the consumer sector's future performance will highly depend on how quickly the economy will recover. As consumers will remain cautious with their expenditure over the next periods, businesses need to adapt their offerings and marketing strategy to survive through the pandemic. The following trends will drive business in the Post-COVID-19 world

- De-Globalization: Covid-19 has shown the downsides of globalization, leading 
companies to rethink how they manage their supply chains, especially around purchasing and sourcing. This will probably result in shifts in production locations and customer focus.

- Digitalization and automation: Because of the crisis, companies will try to reduce costs through greater efficiency, while gaining greater control, for example through investments in process automation, e-commerce, innovative software and IT.

- Flexibility: companies will pay much effort on flexibility to protect their margins in future challenging situations.

- Market consolidation: Stronger competitors will acquire weak players or go bankrupt and disappear.

- Price volatility: As supply and demand change more rapidly than usual, many companies' cost and profitability structures, as well as customers' willingness-to-pay will vary, resulting in more frequent price increases and decreases.

- Focus on core competencies: Competition in some industries could increase with companies suffering from financial losses shrinking certain operations and concentrating on high margin businesses in order to make them their core competence.

The impact of these trends and drivers will vary by business type and industry. The researcher believes that the longer the crisis lasts, the higher the more influence of these factors will exist, with the full effects only visible in the medium or long-term.

How are organizations responding to Covid-
19?

As an immediate response to the Covid-19 crisis, the great majority of organizations are rightly prioritizing the health and well-being of employees and other stakeholders such as customers, suppliers and other partners. The organizations have already put heightened health and safety practices in place for their employees and have already established communication mechanisms, relating to Covid-19 measures, for employees, customers and partners. Then, organizations focus on operational practicalities and ensuring that the business stays viable. These include activities focused on reducing costs, negotiating with banks and debt providers on debt service repayment obligations, reviewing creditors and debtors to manage cash flow, delaying investments, and making adjustments to remuneration and employment models.

\section{Conclusions}

and recommendations

This paper offered some initial thoughts on how the Covid-19 pandemic influences marketing philosophy. Fundamental changes to our lives will affect our beliefs, attitudes, and opinions. However, smart marketers need to adapt their policies and methods to satisfy the new reality.

Although the immediate impact of Covid-19 pandemic seems to be evident, but how it'll change our marketing philosophy?, more strict researches needed to detail which changes will prove beneficial within the longer term.

Covid-19 will change the way companies generate revenues, run their operations and interact with their customers and other key stakeholders within the future. Adapting to those differences is not only a challenge but 
also provides a chance for organizations to enhance their market position as first mover advantage will become a good stronger factor after the crisis

To face this unprecedented crisis, organizations need for effective and quick response, to make sure both short-term survival, and build flexibility needed for longer-term recovery. Managers and decision makers need to consider following recommendations:

- Apply the short-term focus: Senior management need to accept the change of focus from strategic to tactical.

- Keep a close eye on your customer: Recognize the requirements of your customers and other stakeholders and confirm you answer these changing needs.

- Develop an elastic plan. Oversee major issues, formulate business contingency plans, coordinate implementation across different departments, and ensure quick responses and speedy decision-making.

- Review company strategies. Re-examine business models. Explore new channels to communicate, supply-chain diversification, new approaches to customer services.

\section{References}

- UN.ORG (2020), 'UN launches COVID-19 plan that could 'defeat the virus and build a better world', available at: https://news.un.org/en/story/2020/03/10607 02, ac- cessed 18 April, 2020.

- Guillen, M.F. (2020), "How businesses have successfully pivoted during the pandemic", available at: https://hbr.org/2020/07/how-businesseshave-successfully-pivoted-during-thepandemic (accessed 7 July 2020).
- He, Hongwei \& Harris, Lloyd. (2020). The Impact of Covid-19 Pandemic on Corporate Social Responsibility and Marketing Philosophy. Journal of Business Research. 116. 10.1016/j.jbusres.2020.05.030.

- Anwar Y. and El-Bassiouny N. (2020) Marketing and the Sustainable Development Goals (SDGs): A Review and Research Agenda. In: Idowu S., Schmidpeter R., Zu L. (eds) The Future of the UN Sustainable Development Goals. CSR, Sustainability, Ethics \& Governance. Springer, Cham.

- Vafainia, Saeid. (2020). Marketing in post COVID-19 era: A guide for marketing managers.

- Kotler, P., \& Zaltman, G. (1971). Societal Marketing: An Approach to Planning Social Change. JOURNAL of MARKETING, 35(3), 3-12.

- Kotler, P., Armstrong, G., Harris, L. C., \& He, H. (2019). Principles of MARKETING (European Edition). London: Prentice Hall.

- Euronews (2020), 'COVID-19: World economy in 2020 to suffer worst year since 1930s Great Depression, says IMF', accessible at: https://www.euronews.com/2020/04/14/

- $\quad$ Ameen, Nisreen \& Choudrie, Jyoti \& Anand, Amitabh \& Jones, Paul. (2020). Special issue proposal Innovative Technologies and Small-Medium Sized Enterprises in Times of Crisis A COVID 19 Call Journal: Information Systems Frontiers. 10.13140/RG.2.2.34404.81282. - Kang, Jun \& Diao, Zihe \& Zanini, Marco. (2020). Business-to-business marketing responses to COVID-19 crisis: a business process perspective. Marketing Intelligence \& Planning. ahead-of-print. 10.1108/MIP05-2020-0217. 
- Nandy, Monomita \& Lodh, Suman. (2020). Post-COVID-19 and Business Analytics. 10.1007/978-981-15-6572-4_10.

- Sheth, Jagdish. (2020). Business of business is more than business: Managing during the Covid crisis. Industrial Marketing Management. 8.10.1016/j.indmarman.2020.05.028.

- Abbruzzese, J., D. Ingram and S. Click (2020), 'The coronavirus pandemic drove life online. It may never return: What passes for normal life now happens almost entirely online', NBC News, 28th March, 2020, available at:

https://www.nbcnews.com/tech/ internet/coronavirus-pandemic-drove-lifeonline-it-may-never-return-n1169956, Accessed 19th April 2020.

- Potts, John (2018). Futurism, Futurology, Future Shock, Climate Change: Visions of the Future from 1909 to the Present.

PORTAL JOURNAL of MULTIDISCIPLINARY INTERNATIONAL Studies. 15. https://doi.org/10.5130/portal.v15i12.5810 .

- Butler, C. (2020). 'How to survive the pandemic', Chatman House: The World Today, 17th April, accessible at: https://www.chathamhouse.org/publication s/twt/how-survive- pandemic, Accessed 19th April 2020. 